\title{
CULTURA E CRIMINALIZAÇÃO: UM ESTUDO DE CASO SOBRE O FUNK NA CIDADE DE PORTO ALEGRE
}

\section{CULTURE AND CRIMINALIZATION: A CASE STUDY OF FUNK IN PORTO ALEGRE}

\author{
Augusto Jobim do Amaral ${ }^{1}$ \\ Ana Luiza Teixeira Nazário²
}

\begin{abstract}
Resumo
O estudo visa a perquirir os processos de criminalização que recaem sobre as manifestações culturais do funk, mormente no contexto da cidade de Porto Alegre/RS, desde a sua mais expressiva representação que é o chamado Baile Funk da Tuka. Para tanto, debruça-se, numa reflexão histórico-política acerca da memória da criminalidade atrelada à perseguição samba-funk até a atual formação de um ethos punitivo refratário aos "proibidões" como manifestação cultural. Assim, pode-se chegar ao palco gaúcho, através de entrevistas semiestruturadas com os frequentadores dos bailes, MC's que conduzem os encontros, bem como com os policias militares responsáveis pelo policiamento ostensivo na região. A crítica construída é resultado da análise de discurso destes atores sociais, focado no produto de diálogos de intervenção participante, os quais dotam o trabalho de contornos únicos na perspectiva de surpreender o poder punitivo em sua dinâmica contundente de desigualdade, sempre propenso a ativar o preconceito e a estigmatização como produtos naturalizados de violência e exclusão sociais.
\end{abstract}

Palavras-chave: Poder Punitivo; Criminologia; Processo de Criminalização; Funk; Estigmatização.

\section{Abstract}

The study aims to discuss the criminalization processes of the cultural manifestations of brazilian funk, especially in the context of the city of Porto Alegre / RS, from its more expressive representation called "Baile Funk da Tuka". Therefore, it focuses on a political-historical memory about crime linked to a hunt of the samba-funk to current formation of refractory punitive ethos of "proibidões" as cultural manifestation. Thus, one can reach the local stage, through semistructured interviews with the regulars of these "bailes", MCs that lead the meetings, as well as with the military police responsible for the ostensible policing in the region. The criticism built is the result of discourse analysis of these social actors, focused on participant intervention dialogues, which endows the work only outlines the perspective of getting the punitive power by suprise in its forceful dynamics of inequality, often prone to turn prejudice and stigmatization as naturalized products of violence and social exclusion.

Keywords: Punitive Power; Criminology; Process Criminalization; Funk; Stigmatization.

\footnotetext{
1 Professor do Programa de Pós-Graduação em Ciências Criminais (mestrado/doutorado) da Pontifícia Universidade Católica do Rio Grande do Sul (PUCRS). Doutor em Altos Estudos Contemporâneos (Ciência Política, História Contemporânea e Estudos Internacionais Comparativos) pela Universidade de Coimbra (Portugal). Doutor em Ciências Criminais pela PUCRS. Pesquisador-convidado do lus Genitum Conimbrigae (Centro de Direitos Humanos) da Universidade de Coimbra (Portugal). E-mail: guto_jobim@hotmail.com

${ }^{2}$ Graduada em Direito e Especialista em Ciências Penais pela Pontifícia Universidade Católica do Rio Grande do Sul (PUCRS). E-mail: teixeiranazario@gmail.com
} 
Eu sou o samba

A voz do morro sou eu mesmo sim senhor Quero mostrar ao mundo que tenho valor Eu sou o rei do terreiro

Eu sou o samba

Sou natural daqui do Rio de Janeiro

Sou eu quem levo a alegria

Pra milhões de corações brasileiros

(CARTOLA, A Voz do Morro)

\section{PRIMEIROS TONS}

A reflexão sobre a questão criminal, sobretudo como genuína expressão cultural, jamais foi desprezada pelo pensamento político-criminológico. Ao menos por aquele digno, responsável e preocupado em ser convocado assim. ${ }^{3}$ Se as diversas configurações do poder punitivo podem ser identificadas como a forma pela qual certos modos de existência foram perseguidos, suprimidos e apagados da história, assim, precisamente, são e foram estes restos culturais que preenche (ra) m e se amontoa (ra) m progressivamente sob o horizonte como uma torrente de aniquilação que formam aquilo que eufemisticamente chama-se de sistema penal. Vulnerabilidades sociais marginalizadas (marginais ao menos desde o ponto de vista da decisão acerca da exceção ditada pelos soberanos do capital, mas centrais e extremamente funcionais para a sua própria manutenção) desde processos de estigmatização (imagens projetadas dos medos, não raro cristalizados em ódio) e especializadas ainda em direção à criminalização (orientada ao pânico social na busca desenfreada pela figura do inimigo) - todos estes fluxos apenas são operadores capazes de representar o radical ímpeto de guerra à diferença a partir da supressão daquilo que é a força da sua estranheidade (unheimlichkeit): a pluralidade (radical e precária) que não cessa de colocar em xeque o conjunto bem acabado das maquinarias identitárias (entendidas aqui como blocos unívocos de sentido, muito bem encontradas nas engrenagens do sistema penal sob seu "moinho de moer gente"). Inquietantes ruídos da alteridade insistentemente calados penalmente, todavia que, aos interesses pontuais deste trabalho, ecoam suas memórias como pré-texto. Para que não se perca o feixe entrelaçado aqui, desde já, deve-se dizer diretamente: expressões culturais, nos seus precisos nuances, sempre puderam ser o combustível do inflamável movimento do poder punitivo.

\footnotetext{
${ }^{3}$ Em bom resumo, entre outros, cf. FERRELL; HAYWARD; MORRISON; PRESDEE, 2004.
} 


\section{SAMBANDO SOB AS MATRIZES DA PERSEGUIÇÃO AO FUNK}

Ontem os batuques acoçados nas senzalas, hoje o funk perseguido nos bailes. O mesmo público, o mesmo azimute étnico orientado por iguais argumentos legitimadores da repressão. A repulsa às expressões culturais inferiorizadas compõe a nota repetida do preconceito violentamente naturalizado na sociedade brasileira desde o seu "encobrimento" até hoje - e nem precisamos dispor de maior exame do traço permanente do genocídio colonial ocorrido nos povos indígenas no Brasil reproduzido ainda como prática institucionalizada no presente. Nada diferente, ademais, quando da chegada dos africanos trazidos sob a condição de escravos e dispostos como meros objetos de mão-de-obra.

Todavia, esta mentalidade que impulsiona "moinhos de gastar gente" não faria calar as contribuições elementares para a formação do caleidoscópio que poderíamos hoje chamar de cultura brasileira (RIBEIRO, 1995, pp. 106 ss.). Oriundos de diferentes grupos étnicos africanos ${ }^{4}$ possuíam linguagem e práticas culturais distintas as quais, paulatinamente, agregaram-se e formaram o que hoje integra nosso modo de ser. Em que pese tal bagagem cultural riquíssima com a qual fomos presenteados, este patrimônio foi e permanece sendo alvo de negação e perseguição. Portanto, os segmentos étnico-culturais das classes ditas subalternas, disseminados nas camadas periféricas da sociedade brasileira, numa clara linha de permanência, têm sido sempre sujeitos de processos de marginalização e criminalização. Neste sentido, resumidamente Vera Malaguti Batista afirma:

"Na história brasileira, as estratégias de sobrevivência, de lazer, a arte de curar, as religiões e as manifestações culturais de matrizes africanas foram sempre criminalizadas: do samba ao funk." (BATISTA, 2011, p. 76-7).

Muito desse processo se deve à notória supervalorização de uma cultura imposta como "hegemônica", pois, ainda que nossa sociedade seja composta por um hibridismo cultural ímpar, tal pluralidade é constantemente negligenciada. Notadamente, muitas vezes o ambiente escolar exclui de seu currículo os saberes sobre as culturas para além da Europa, corroborando com o silenciamento de grupos que, historicamente, são vítimas de discriminação.

Antes mesmo de se tentar entender o atual caráter da criminalização de determinadas "subculturas" 5 , em especial o processo de criação e distribuição do rótulo "negativo" imposto ao

\footnotetext{
${ }^{4}$ Nagôs, mandingas, tapa, jejes, mina, fulas, negros da guiné, haussás, bornu, gurunsi, malês e outros. RIBEIRO, 1995, pp. 113 ss.

${ }^{5}$ Subculturas criminais, questão fundamental (ainda que terminologicamente controversa por poder deixar antever uma perspectiva que colocaria determinadas para culturas como qualitativamente inferiores, assim transparecendo uma ideia de hierarquia cultural) desenvolvida por COHEN, 1955.
} 
funk e seus artistas, é necessário pensar historicamente, relembrando as perseguições sofridas pelas demais manifestações das culturas periféricas, em especial à cultura negra.

Adriana Facina defende que:

"O que o funk como um todo, e não só o proibidão, pode ser considerado um capítulo de uma história mais antiga de criminalização da cultura negra no Brasil. A perseguição aos batuques que vinham das senzalas, à capoeira, ao maxixe, ao samba, entre outros, fez parte da formação da nossa sociedade, profundamente opressiva com os debaixo. " (FACINA, 2013, p. 57).

Daí não se pode perder o essencial com relação ao proibicionismo seletivo - marca indelével do sistema penal - drama recalcado e aprofundado em nossa sociedade que não cessa dar seu testemunho:

"Antigamente era proibido batuque, lundu. Depois da Revolução de 1930, Getúlio Vargas descriminalizou a capoeira, o candomblé. [...] Então o funk, olhando em longo prazo, é um pouco a história do 'retorno do recalcado'. O mesmo que aconteceu com a capoeira e o com o samba acontece agora com o funk." (MEDEIROS, 2006, p. 32).

Exemplo disso é o Código Penal de 1890 (PIERANGELI, 2001) que, em grande parte, destinava-se à repressão das manifestações do estrato mais vulnerável da sociedade: o mesmo público alvo da "Seção de Entorpecentes Tóxicos e Mistificação", delegacia responsável, dentre outros casos, por coibir além dos cultos de origem africana, a prática de capoeira, rodas de samba e combater o uso de Cannabis Sativa (GABEIRA, 2000) utilizada em rituais como o Candomblé.

Pontualmente, a respeito do samba, ritmo originário do Lundu (ou Lundum) ${ }^{6}$ inicialmente conhecido como "batuque" ou "umbigada" e hoje reconhecido como patrimônio cultural do Brasil, seu histórico de perseguição e repressão no início do século XX se faz sob a lógica muito semelhante quando comparadas ao processo envolvendo o funk.

Ainda que existissem diversas formas de samba no Brasil provenientes do batuque (ritmos sincréticos ainda hoje de difícil classificação), o samba como gênero musical pode ser percebido desde há muito como uma expressão musical urbana do Rio de Janeiro. Isto se deu, na virada do XIX para o XX, quando da queda da produção de café e da abolição da escravatura, momento em que os ex-escravos, principalmente aqueles que viviam no sertão baiano, acabaram por migrar para a então capital do país (Rio de Janeiro), estabelecendo-se, em sua maioria, nas comunidades cariocas da Gamboa e da Saúde (MOURA, 1995, pp. 44 ss.).

\footnotetext{
${ }^{6}$ Gênero musical e dança folclórica de influência luso-africana criado na segunda metade do século XVIII a partir dos batuques dos escravos. Sobre a historiografia do samba, cf. MOURA, 1995. Sobre a imensa controvérsia sobre a pré-história do samba, em especial a posição de que o samba não é de origem negra, mas brasilíndia, nem carioca, mas nordestina, ver ALVES FILHO, 2002.
} 
A partir dessa migração em massa, responsável pelo crescimento vertiginoso dos índices demográficos do Rio de Janeiro no final do século XIX, impulsionou-se uma fusão étnico-cultural responsável em grande medida pelos contornos de parte da contemporânea pela formação do povo brasileiro. Não nos esqueçamos do especial espaço ocupado neste processo pelo protagonismo das conhecidas "Tias Baianas": mulheres baianas descendentes de africanos que foram escravizados e traficados para o Brasil. Estas mulheres eram líderes comunitárias que ajudavam e acolhiam os ex-escravos recém-chegados ao Rio de Janeiro. Suas casas serviam não só de abrigo, mas também como ponto de referência e de contatos para a comunidade negra, possibilitando a integração na sociedade e o apoio necessário para a sobrevivência na cidade (VELLOSO, 1990, p. 209).

Além da função solidária das casas das "Tias", elas eram grandes espaços de fortalecimento dos laços étnicos e de conservação das tradições do povo africano, seja sob o aspecto religioso, gastronômico ou musical. Sinteticamente, as casas das Tias Baianas foram verdadeiros centros de desenvolvimento da cultura afro-brasileira. Para ter-se uma ideia, a casa da Tia Ciata (MOURA, 1995, pp. 85-106), considerada a Tia Baiana mais famosa, foi cenário para a composição d o primeiro samba a ser gravado no Brasil: Pelo Telefone de Ernesto dos Santos (Donga) ${ }^{7}$, em 1917. As festas promovidas por Tia Ciata contavam com a presença de Donga, Sinhô e João da Baiana, os primeiros compositores de samba, e também de intelectuais como Manual Bandeira e Mário de Andrade.

Nas casas das Tias Baianas aconteciam sessões de Candomblé e rodas de samba que duravam dias, sem jamais se esquecer que estas festas e cultos eram constantemente interrompidas pela polícia, que alegava os standards nada ausentes hoje de "perturbação à ordem pública", "vadiagem" e "crimes contra a saúde pública" como argumentos para acabar com o lazer dos negros e, naturalmente, prendê-los. "Quem portava um instrumento musical ou fazia samba podia ser enquadrado como vadio [...] Os sambas sofriam uma espécie de patrulhamento, no sentido da não exaltação dessa figura do malandro que despreza o trabalho. " (FRAGA, 2013).

Mesmo que atualmente a realidade do samba não seja exatamente a mesma, não estando estritamente vinculado ao morro como antes, tendo conquistado largos estratos da classe média e tornando-se excelente produto do segmento mercadológico musical, a racionalidade estigmatizante amparada pela segregação social e penal, não tarda a manter o compasso nada

\footnotetext{
7 Canção composta em 1916, no quintal da casa da Tia Ciata, na Praça Onze. A melodia, originalmente, intitulava-se Roceiro e foi uma criação coletiva, com participação de João da Baiana, Pixinguinha, Caninha, Hilário Jovino Ferreira e Sinhô, entre outros. Cf. MOURA, 1995, p. 117.
} 
surdo da criminalização de minorias nela estampadas. Os batuques que conquistaram ouvidos e pés pelo mundo afora como ritmo tradicionalmente suburbano, ainda que tenha deixado de ser meramente "um som do morro" e tendo ganho notoriedade e reconhecimento como um dos símbolos da cultura brasileira, o racismo não deixa de se esgueirar para atar tal estética à ética do preconceito.

Ao analisar o histórico do samba, podemos dizer, não sem uma certa dose de risco, porém nada absurdo, que as complexas metamorfoses culturais as quais passou a música dita popular, como expressão de modos de vida múltiplos - o samba em particular - não deixou de gerar, sob novos contextos, frutos riquíssimos. Um deles particularmente importante é o funk. Longe de qualquer causalismo simplificador, não obstante, nada distante da realidade, pode-se enxergar o funk também como herdeiro do samba. Tal qual o samba, sob os traços de comunidades vulneráveis socialmente, estigmatizadas e criminalizadas, em alguma medida, está o funk. Protagonizadas por negros e pobres, vemos, novamente, a cultura originária da favela recebendo todo peso da marginalização e, politicamente, associada à violência, à selvageria e à criminalidade.

Por outro lado, lembremos também o perene questionamento comum a ambas manifestações culturais sobre a generalização da falta qualidade, talento ou diretamente a "pobreza musical". Argumentos recorrentes e simétricos em ambas circunstâncias:

"o que hoje lemos como poesia nos sambas mais antigos, tratava-se da linguagem coloquial da época. Eram jovens, falando para jovens, retratando a realidade em que viviam, no ritmo em que viviam. [...]. As extensas citações aos nomes das comunidades e aos próprios cantores que aparecem nas letras de funk hoje [...] sempre aconteceram no samba. Noel Rosa, Nelson Cavaquinho e Cartola já utilizaram esse recurso. " (MEDEIROS, 2006, p. 33-4)

Para seguir no exemplo, o saudoso Agenor de Oliveira, nosso mestre Cartola, considerado por diversos músicos e críticos como o maior sambista da história da música brasileira, por vezes citava nos seus versos, em linguagem própria, o Morro da Mangueira, comunidade que o acolheu aos 11 anos e de onde nunca mais se afastou. Presente nas letras de "Mangueira é muito grande" (canção de Ataliba interpretada por Cartola de 1973), "Sala de Recepção" (1976), "Escurinha" (Samba dos mangueirenses, de Geraldo Pereira e Arnaldo Passos, revisitado por Cartola de 1977) e "A Mangueira me chama" (1978), sua comunidade era motivo de orgulho e inspiração para o compositor.

O fundamental é destacar que o elo samba-funk reside no apelo à identidade negra e à origem na favela entre as camadas mais pobres, mas também na apropriação do discurso de resistência e de apego à comunidade. Como lembra Écio Salles, 
"em sambas ou funks muito conhecidos, como 'A voz do morro', de Zé Ketti; ou 'Eu só quero ser feliz', de Cidinho e Doca, percebe-se de forma exemplar essa espécie de reivindicação da referência ao morro ou favela como seu lugar de origem". (SALLES, 2007).

Cabe esclarecer que não se busca afirmar que o funk é uma espécie de novo samba, mas sim que esses ritmos dividem o mesmo espaço sociocultural, como bem explica Micael Herschmann:

\begin{abstract}
"Estamos longe de constatar a substituição do samba pelo funk, mas reconhecemos que o primeiro, enquanto prática sociocultural, tem cedido significativo espaço ao segundo, principalmente entre os jovens dos segmentos populares." (HERSCHMANN, 2000, p. 220).
\end{abstract}

As perseguições aos batuques e ao samba "encontraram no funk um novo alvo à altura da tradição: também uma arte popular, cultivada pelos estratos sociais mais pobres, irreverente e sensual. " (BATISTA, 2013, p. 191). Nada de "coincidências", o que acontece hoje com o funk é a expressão transmutada de uma mesma lógica de criminalização da cultura negra.

\title{
NO RITMO “PROIBIDÃO”
}

\author{
Quero paz, quero festa Funk é do povão \\ Já cansei de ser visto com discriminação \\ Lá na comunidade funk é diversão \\ Hoje eu tô na parede ganhando uma geral \\ Se eu cantasse outro estilo isso não seria igual \\ (CIDINHO \& DOCA, Não me bate doutor)
}

Nos anos noventa aparecem nuances perfeitamente identificáveis no funk que passaram a merecer destaque. ${ }^{8}$ Nesta época, propagados através de fitas cassetes e CDs "piratas", surgem os "proibidões": funks com letras que narram o cotidiano dos moradores dos morros e favelas brasileiras, ou seja, cantam o tráfico de drogas, exaltam facções criminosas, falam sobre a rotina dos tiroteios entre criminosos e a polícia e banalizam o sexo.

Esse segmento do funk ganhou o nome de "proibidão" devido a sua execução em rádio ou televisão ser impedida. ${ }^{9}$ Entretanto, com o avanço tecnológico, hoje pode ser escutado sem

\footnotetext{
${ }^{8}$ No Brasil, a partir dos anos de 1970, bailes black, soul e funk começaram a ser realizados no Rio de Janeiro. Ainda que hoje o funk carioca seja uma manifestação cultural predominante suburbana, os primeiros bailes foram realizados na casa de shows "Canecão", localizada no Bairro de Botafogo, Zona Sul do Rio de Janeiro. O "Baile da Pesada", que ocorria aos domingos, era organizado pelo discotecário Ademir Lemos e pelo animador e locutor de rádio Big Boy (Newton Duarte). Para toda a extensa e destacada consolidação do "mundo funk carioca", ver VIANNA, 1987.

${ }^{9} \mathrm{Com}$ a popularização do ritmo, os bailes se multiplicaram, porém, em contrapartida, o funk se tornou vítima de perseguições e preconceito da sociedade. A discriminação se deve além do funk ter se difundido entre as camadas mais pobres da sociedade, mas também pela ocorrência dos "corredores" em alguns bailes. Os
} 
restrição em sites de vídeos e redes sociais e seu download é de fácil acesso por todos. Para Messenger,

"O "proibidão" é o funk que conta de forma realista, entusiástica ou apologética histórias em que traficantes impõem seu poder contra seus oponentes, sejam estes a polícia, os delatores ou outras facções criminosas. " (ESSINGER, 2005, p. 59).

Com o surgimento dos "proibidões" (em paralelo com a exploração eleitoral da montagem midiática sobre o famoso episódio do "Arrastão de 1992" na praia do Arpoador no Rio de Janeiro ${ }^{10}$ ), o funk passou a ocupar menos espaço nos cadernos culturais e a marcar mais presença nos cadernos policiais. Dinâmica traz as raízes da manipulação do medo como forma de legitimar práticas de segregação social bem ao gosto brasileiro.

Micael Herschmann aponta que, entre 1990 e 1991, o funk era tema de todos os cadernos culturais. Contudo, em 1992, o ritmo ocupava $94,8 \%$ dos cadernos locais e policias, contra apenas 5,2\% dos cadernos culturais (HERSCHMANN, 2000, p. 52). A partir disso, a ameaça de proibição dos bailes se tornou constante. A proibição e limitação do horário dos bailes e a instauração de inquéritos para investigação de "apologia ao crime" nas letras de MCs foram e permanecem ainda como algumas das estratégias, não só para silenciar a cultura funk, mas, sobretudo, para segregar e tornar mais invisível seu público: a figura demonizada do jovem negro morador da periferia.

Sobre as acusações imputadas aos MCs, Danilo Cymrot aduz:

"Quando não são acusados de fazer letras pobres e alienadas, os MCs são acusados de compor músicas que fazem apologia ao crime, taxadas de "proibidões". Por outro lado, consumo de drogas e violência existem em praticamente todos os locais de divertimento de jovens, inclusive em "baladas" caras de bairros nobres, mas nem por isso a polícia proíbe tais festas." (CYMROT, 2015).

Se é inegável que uma parte da produção musical do funk é marcada, mesmo nas letras, pela presença do tráfico de drogas e das facções criminosas - afinal, é o ambiente que prepondera e sob o qual estão mergulhadas estas comunidades, há que se dizer, com enorme cumplicidade estatal -, contudo não se pode reduzi-los em sua totalidade a isso, ignorando, por exemplo, os funks de denúncia, de crítica social e mesmo aqueles sem qualquer cunho ideológico expresso, normalmente em sua maioria de conteúdo bem-humorado e pornográfico (MARTINS, 2006, p. 74).

bailes eram divididos em "lado A" e "lado B" para que houvesse confronto entre as galeras rivais, resultando em agressões e até em mortes. Considerando a complexidade etnográfica dos Bailes de Corredor e que tal aprofundamento não é o objetivo do presente trabalho, remetemos a VIANNA, 1997.

${ }^{10}$ Para bom resumo, ver FRANCISCO, 2016. 
Estes contextos de vida precários versados ali naturalmente apenas lidam com a realidade dos moradores de áreas pobres. Longe de produzirem apologia ao crime, relatam o que acontece diariamente nas favelas e morros do Brasil:

"Não significam adesão ao tráfico; muitas das vezes, seus compositores
sequer sabem explicar o que os motivou a assim se expressar: se a pura
diversão, o "gosto do proibido", a vontade de desenvolver uma boa relação
com a comunidade e os poderes locais etc. Todas estas possiveis
justificativas passam a segundo plano quando se constata que, para muitos
MCs, as circunstâncias de criminalidade e pobreza que lhes cercam Ihes são
tão naturais e onipresentes que estes não as diferenciam a priori,
ontologicamente, dos demais elementos estruturantes de suas canções. A
um habitante de áreas pobres, pareceria estranho raciocinar em termos de
não poder mencionar livremente o tráfico, a violência policial e a ausência do
poder público ao retratar sua comunidade." (MARTINS, 2006, p. 75) Wagner Domingues da Costa, mais conhecido como Mr. Catra, é um dos mais destacados nomes do funk e uma das vozes mais reconhecidas do proibidão. Figura lendária pelo seu jeito nada convencional de viver ${ }^{11}$, Mr. Catra explica o real sentido da polêmica vertente do funk e provoca:

"O proibidão é feito para ser cantado no baile. Não é uma apologia ao crime, mas um relato da minha comunidade. $O$ funk nasceu na favela e infelizmente o tráfico também faz parte dela. A sociedade não está preparada para compreender o proibidão, porque quem não sofre não dá valor ao sofrimento. Quem não vive no morro não sabe o que acontece lá. " (ESSINGER, 2005, p. 235).

Assim, é possível interpretar os "proibidões" como discursos que combatem o silêncio e contestam a paz seletiva. Interferem naquele sossego desfrutado pelas classes dominantes por produzirem uma memória acerca da criminalidade. Como explica Cymrot,

"São o instrumento para se ouvir a voz dos setores marginais da nossa sociedade, são a 'história vista por baixo', uma memória coletiva subterrânea, clandestina, sufocada, que entra em choque com a memória coletiva oficial, a qual a sociedade majoriatamente ou o Estado desejam impor." (CYMROT, 2015, p. 93-4).

Por outra parte, não se pode ignorar o processo de empatia e identificação dos jovens moradores de favelas com os traficantes e líderes de facções. Muito presente o mito do bandido Robin Hood, termo utilizado pelo historiador Eric Hobsbawm na obra "Bandidos" (1969), na qual explora o conceito de banditismo social. O traficante é admirado por sua valentia e também pelas benfeitorias que exerce, tal qual o herói mítico inglês: "tira dos ricos para dar aos pobres". O historiador britânico pontifica:

11 Catra tem 30 filhos (entre biológicos e adotivos) e mantém um relacionamento amoroso com três mulheres. Todos vivem na mesma casa, no bairro da Glória, centro do Rio de Janeiro. 
"O bandido é bravo, tanto em ação e como vítima. Morre desafiadoramente e com dignidade, e inúmeros nada possuem senão o dom comum, porém precioso, de força e coragem, identificam-se com ele. Numa sociedade em que os homens vivem da subserviência, como escravos de máquinas de metal ou como peças moventes de maquinaria humana, o bandido vive e morre de cabeça erguida." (HOBSBAWM, 1976, p. 132-133).

São eles representações de subjetividades que, apesar de fadadas a uma existência efêmera, quase que monopolizam, principalmente sobre os jovens, muito para além do sucesso financeiro, os desejos de reconhecimento, respeito e visibilidade social. Não obstante, a tirania do tráfico vai tentar ser respaldada também pelas práticas assistencialistas, adotadas para alcançar o apoio da comunidade:

"Almejando obter o apoio da comunidade, o bandido Robin Hood adota práticas assistencialistas e clientelistas, doando alimentos, remédios, roupas, brinquedos e investindo em asfalto, iluminação e lazer paras os moradores, como quadras de esportes, piscinas, escolas de samba e, claro, bailes funk. " (CYMROT, 2015, p. 81).

Como lembra Salles, ainda que não existam composições tais como as do funk, há notórias repetições históricas na música popular brasileira, até mesmo no samba, de um elogio poético ao banditismo e temas relacionados (SALLES, 2007). Exemplo disso está em Bezerra da Silva, como no samba "Meu Bom Juiz" (composição de Beto Sem Braço e Serginho Meriti), em homenagem ao traficante carioca Escadinha (alcunha de José Carlos dos Reis Encina, um dos fundadores da facção Comando Vermelho):

"Ah, meu bom juiz / Não bata este martelo nem dê a sentença / Antes de ouvir o que o meu samba diz / Pois este homem não é tão ruim quanto o senhor pensa / Vou provar que lá no morro / Ele é rei, coroado pela gente / É que eu mergulhei na fantasia e sonhei, doutor / Com o reinado diferente / É mas não se pode na vida eu sei / Sim, ser um líder eternamente / Homem é gente / Mas não se pode na vida eu sei / Sim, ser um líder eternamente / Meu bom doutor, / O morro é pobre e a pobreza não é vista com franqueza / Nos olhos desse pessoal intelectual / Mas quando alguém se inclina com vontade / Em prol da comunidade / Jamais será marginal / Buscando um jeito de ajudar o pobre / Quem quiser cobrar que cobre / Pra mim isto é muito legal / u vi o morro do juramento, / Triste e chorando de dor / Se o senhor presenciasse chorava também doutor." (SILVA, 2003).

Embora sejam reprovados veementemente de maneira geral, os "proibidões" - que exaltam chefes do tráfico, expõem atos criminosos e narram conflitos entre as facções e a polícia têm como referência temática o cotidiano da favela. Se Bezerra da Silva e outros sambistas romantizavam a malandragem do morro, os "proibidões" por sua vez, de certo modo, reatualizam tal estética para enaltecer seus (anti) heróis (SALLES, 2007). 
Não há como deixar de reconhecer que o "proibidão" perturba porque escancara uma realidade que os domesticados olhos e ouvidos da sociedade brasileira preferem não ver e silenciar. A transformação da realidade de injustiça social sempre é mais difícil do que a pura repressão de seus relatos: "O verdadeiro crime de apologia é a cumplicidade do Estado no extermínio de uma juventude favelada para a qual o tráfico é o 'pis aller'. " (PALOMBINI, 2013, p.150-1). Como Mr. Catra canta: “Favela não é só crime / Favela também é arte" (Mr. CATRA, 1999). Sobretudo, é a arte de sobreviver.

\title{
O PALCO GAÚCHO DO FUNK: O CASO DO BAILE FUNK DA TUKA EM PORTO ALEGRE
}

\author{
A Tuca é só lazer e o movimento tá fluindo \\ Tá tudo dois, tá tudo lindo \\ Pra quem desacreditou, eu tô aqui pra dizer \\ Que os moradores estão tranquilos e as crianças \\ no lazer \\ "Nois" tem baile pra curtir, até campo de futebol \\ Tem praça pra "marolar", relaxar vendo o pôr-do- \\ sol \\ Aqui também tem respeito, também somos \\ educados \\ Mas a mídia nos oprime por que somos favelados \\ Lado a lado e curtindo, sempre juntos com os \\ irmãos \\ Só quem fecha com a Tuca, por favor, levanta a \\ mão \\ (MC TON, Tá tudo dois, tá tudo lindo)
}

Embora Porto Alegre seja bastante conhecida pelas bandas de rock que alcançam sucesso nacional (cf. PINTO; BORBA, 2014), o funk também repercute profundamente na capital dos gaúchos. O espaço foi aberto pelo ritmo no fim da década de 1990 e pode-se dizer um dos protagonistas por esta inclusão foi o radialista Walmir Filho ${ }^{12}$. Ainda que, quando tenha chegado aqui, o gênero já tocasse nas rádios e nas festas de clubes, com o espaço que tinha (e ainda tem) na Rádio Eldorado FM, Walmir contribuiu muito para que, no início dos anos 2000, o funk se consolidasse como manifestação cultural em Porto Alegre (PEREIRA, 2010, p. 24):

\begin{abstract}
"A Rádio Eldorado Ihe cedeu espaço para programas inteiramente dedicados ao estilo musical, e com o crescimento da audiência, a rádio passou a ter a programação inteira dedicada ao funk. Foram segundo Walmir, quatro anos no primeiro lugar em audiência com a programação de $24 \mathrm{~h}$ de funk. As festas se proliferaram, mas sempre nos subúrbios. Nas periferias, hoje, realiza-se um grande número de bailes por semana. Walmir diz ter
\end{abstract}

\footnotetext{
12 Walmir Filho, carioca, é DJ da Rádio Eldorado 97.5 FM de Porto Alegre, especializada em funk e pagode.
} 
normalmente mais de 10 lugares para se apresentar por final de semana. Neste caso, festas e bailes totalmente direcionados ao funk ou com artistas de estilos atualmente igualmente admirados pelos frequentadores desses bailes, como pagode e hip hop." (PEREIRA, 2010, pp. 24-5).

Devido à quantidade de festas funk realizadas em Porto Alegre, o radialista acredita que a capital já está em segundo lugar no país como centro de bailes do estilo. Entretanto, semelhante ao que ocorre no Rio de Janeiro, Walmir pondera que não há espaço na mídia, pois "a música produzida na periferia sempre vai ser vista com preconceito pelos grandes veículos de comunicação" (PEREIRA, 2010, p. 25).

Atualmente, o estado conta com muitos representantes do ritmo que ganharam notoriedade nacional, a exemplo de $M C$ Jean Paul ${ }^{13}$ que hoje apresenta um programa de funk na Rádio Farroupilha FM (antiga Rádio Cidade 92.1 FM) e os MCs Tchesko e Dino, sucessos do chamado funk ostentação.

MC Jean Paul alcançou projeção tal que, em 2007, conseguiu levar o funk para o palco do centenário Theatro São Pedro em Porto Alegre, acompanhado da Orquestra Sinfônica de capital. Desde sempre percebe a atmosfera de preconceito que está imerso o ritmo:

"É bom deixar claro que a pessoa é livre para escutar o que ela quiser. O pessoal geralmente cai em cima do funk porque é um ritmo da periferia. Qualquer outro ritmo musical tem músicas que falam de sensualidade, de sexo, e ninguém fala nada. O funk sempre vai ser rotulado" (PRESTES, 2012).

No ano de 2010, pelo Decreto no 10.987/2010, o funk foi reconhecido como "Movimento

Cultural e Musical de Caráter Popular do Município de Porto Alegre":

“LEI № 10.987, DE 6 DE DEZEMBRO DE 2010.

Reconhece o funk como um movimento cultural e musical de caráter popular do Município de Porto Alegre e dá outras providências.

O PREFEITO MUNICIPAL DE PORTO ALEGRE.

Faço saber que a Câmara Municipal aprovou e eu, no uso das atribuições que me confere o inciso II do artigo 94 da Lei Orgânica do Município, sanciono a seguinte Lei:

Art. 10: Fica reconhecido o funk como um movimento cultural e musical de caráter popular do Município de Porto Alegre.

Art. 2:: Fica assegurado ao movimento funk:

I - Realização de festas, bailes e reuniões, sem quaisquer regras discriminatórias ou diferentes das que regem outras manifestações da mesma natureza;

II - Proteção quanto a qualquer tipo de discriminação ou preconceito de natureza social, racial, cultural ou administrativa, inclusive a seus integrantes;

III - reconhecimento de seus artistas como agentes da cultura popular e respeito aos seus direitos;

${ }^{13}$ Embora paulista, reside na capital desde os 14 anos e deu início a sua carreira aqui no ano de 2002. 
IV - Condições para que a diversidade de sua produção musical possua veículos de expressão, mediante:

a) a disponibilização de espaços públicos para apresentações; e

b) a conscientização sobre seus direitos, bem como a promoção desses.

Art. 3o: O Executivo Municipal, por meio da Secretaria Municipal da Cultura, zelará pelo cumprimento do disposto nesta Lei.

Art. 4ㅇ: Esta Lei entra em vigor na data de sua publicação.

PREFEITURA MUNICIPAL DE PORTO ALEGRE, 6 de dezembro de 2010.

José Fortunati,

Prefeito" (DOPA, 2010).

Em 2014, o Vereador Mário Fraga (PDT-RS) apresentou projeto de lei que incluiu a efeméride "Dia do Funk" no Calendário de Datas Comemorativas de Conscientização do Município de Porto Alegre. O projeto foi aprovado e, em setembro do mesmo ano, foi sancionado pelo prefeito José Fortunati, tornando-se a Lei no 11.682/2014 e assegurando ao movimento funk o dia 31 de maio como sua data oficial.

“LEI № 11.682, DE 25 DE SETEMBRO DE 2014.

Inclui a efeméride Dia do Funk no Anexo da Lei no 10.904, de 31 de maio de 2010 - Calendário de Datas Comemorativas e de Conscientização do Município de Porto Alegre -, e alterações posteriores, no dia 9 de junho.

O PREFEITO MUNICIPAL DE PORTO ALEGRE

Faço saber que a Câmara Municipal aprovou e eu, no uso das atribuições que me confere o inciso II do artigo 94 da Lei Orgânica do Município, sanciono a seguinte Lei: 10.904, de 31 de maio de 2010 - Calendário de Datas Comemorativas e de Conscientização do Município de Porto Alegre -, e alterações posteriores, no dia 9 de junho.

Art. 1o: Fica incluída a efeméride Dia do Funk no Anexo da Lei no 10.904, de 31 de maio de 2010 - Calendário de Datas Comemorativas e de Conscientização do Município de Porto Alegre -, e alterações posteriores, no dia 9 de junho.

Art. 2: Esta Lei entra em vigor na data de sua publicação.

PREFEITURA MUNICIPAL DE PORTO ALEGRE, 25 de setembro de 2014.

José Fortunati,

Prefeito.

Luiz Fernando Moraes,

Secretário Municipal de Turismo" (DOPA, 2014).

Conquanto seja legalmente reconhecido como movimento cultural, a não aceitação e o preconceito seguem presentes na trajetória do funk gaúcho. Entretanto, aos poucos, barreiras são superadas e o funk vem ganhando cada vez mais espaço no Rio Grande do Sul. Na capital, os bailes são realizados desde a Zona Sul à Zona Norte. Há enorme difusão independente do estrato social: Caldeirão da Bonja, Adegas, Casablanca e Mansão são apenas alguns exemplos das casas em que as festas são promovidas na cidade.

Não obstante, entre as dezenas de bailes funk que são realizados em Porto Alegre, um chama a atenção pela tradição e respeito que conquistou: o Baile Funk da Tuka. Há mais de uma 
década na zona leste da capital, mais precisamente na Rua A, № 71, no Campo da Tuca (Partenon), o baile, que já está na terceira geração ${ }^{14}$, é considerado referência nacional, sendo o maior palco de funk do sul do país, atraindo holofotes e trazendo atrações de projeção nacional.

No dia 05 de setembro de 2015, chegou-se na comunidade da Tuca por volta das 19h30min, onde houve o encontro com dois produtores do baile, Pablo Fidelis e Anderson Moreira, que gentilmente apresentaram o espaço destinado ao baile, responderam aos questionamentos e, depois, obviamente, convidaram para a festa ${ }^{15}$.

O baile começou em um espaço pequeno, onde a entrada custava apenas $R \$ 2,00$ (dois reais) até comportar a estrutura que hoje possui. Organizado pela produtora Sindicato $M C^{\prime} s^{16}$, hoje o baile atrai público de todos os gêneros e classes, sendo considerado como o mais seguro da capital ${ }^{17}$, no qual frequentadores podem se divertir com certa tranquilidade. Devidamente licenciado pela Secretaria Municipal de Produção, Indústria e Comércio (SMIC), o espaço comporta 3.500 (três mil e quinhentas) pessoas em dois andares divididos entre pista, camarote na área superior e espaço VIP próximo ao palco.

A segurança é rígida, naturalmente sendo proibido o consumo de drogas ilícitas. Brigas, discussões ou abusos não são consentidos, e quem desobedecer às regras da casa é advertido pelos seguranças. Caso haja insistência, a expulsão do evento é a medida adotada ${ }^{18}$. Neste sentido, destaca-se a declaração de um dos frequentadores do baile: "O negócio qqui é sério, entendeu? Não tem ladaia. É diferente da Mansão, do NH Hall... O respeito é cobrado dentro do baile. Não pode usar droga lá dentro" (ANEXO, 7.4).

Diferente dos outros bailes e festas, inclusive e principalmente as de "elite", a mulher é respeitada. Durante os três bailes que se presenciou, e também pelo relato das entrevistadas, abusos ou "investidas" mais contundentes não eram toleradas, tanto pelos demais frequentadores como pelos seguranças. As mulheres (em sua maioria adolescentes entre 16/19 anos), com shorts

\footnotetext{
${ }^{14}$ Segundo definição dos produtores do baile, "geração" é a evolução da festa a partir do sucesso que alcança, isto é, a melhoria na qualidade do evento, nível das atrações e estrutura do baile.

${ }^{15} \mathrm{O}$ baile do dia contava com a atração nacional MC Kauan, conhecido também como "Koringa". Nesta oportunidade, a casa chegou a sua lotação máxima.

${ }^{16}$ Produtora responsável por agenciar a carreira de MCs do Sul do país, a exemplo dos MCs Kinho da Tuka e Ton.

${ }^{17}$ Durante a conversa, os produtores afirmaram até mesmo o apresentador Alexandre Motta (âncora do programa Balanço Geral da Rede Record, talvez a representação da criminologia midiática de mais baixo conteúdo) afirmou que "o Baile da Tuka é 100\% seguro". Não se localizou o registro da suposta declaração do apresentador.

${ }^{18}$ Conforme relatos dos seguranças do baile, aquele que chega ao ponto da expulsão "pega gancho" por algumas um mês, ou seja, fica proibido de entrar no baile.
} 
curtos, decotes e vestidos apertados, dançam "até o chão" sem serem importunadas. Na oportunidade da entrevista, uma das frequentadoras do baile relata: "Aqui tem respeito e lazer. Esse é o lado bom. Tem um monte de patricinha universitária que vem para cá curtir o baile" (ANEXO, 7.3).

Mesmo ambiente retratado inclusive por quem detém o monopólio midiático de grande circulação no RS através de seu tabloide, em reportagem produzida pelo "Caderno Donna" (culto a futilidades dirigidas ao público feminino e de péssimo conteúdo reflexivo), sobre jovens de classe alta que vão aos morros e vilas de Porto Alegre em busca de bailes funk. Ali encontramos a declaração de uma estudante de Direito de 22 anos e frequentadora do Baile Funk da Tuka:

"O preconceito é enorme, mas entre os jovens isso está mudando. Na faculdade, quando digo que venho aqui, minhas colegas ficam curiosas e me pedem para trazê-las. Tem vindo muita gente de classe alta para cá? " (ZERO HORA, 2013).

Sobre a relação dos moradores da Tuca com o baile, MC Tchesko diz que o baile é um "prêmio", motivo de orgulho dentro da comunidade e também responsável por propiciar lazer aos moradores:

"O baile é muito aceito na comunidade, é um prêmio da Tuka, o baile, é o maior orgulho que eu falo do baile, eles também tem o maior orgulho no peito de ser da Tuka porque o reconhecimento há 9,10 anos já, de um baile funk, hoje é o maior palco do funk do sul do Brasil, tá no campo da Tuca, tenho certeza que os moradores lá tem muito orgulho porque já passaram vários MCs mesmo, é um prêmio que eles tem, tanto que é o baile que garante o prazer de todo o final de semana, vai lá desestressar, deixar a mente fluir, depois do baile, o cara vai se sentir relaxado, se sentir melhor. Acho que, é bem importante ter esse lazer dentro da favela, comunidade como te falei, é um lugar carente, que necessita muito dessa energia que o funk passa, e que o baile, nos dá, e há muito tempo né!?" (ANEXO, 1).

Além do baile, a produtora Sindicato MCs é autora do projeto social "Escola de MCs e DJs", na qual são ministradas aulas de cidadania e oficinas de produção de funk - geralmente com MCs palestrantes - para aproximadamente doze alunos (a maioria adolescentes) duas vezes por semana no mesmo espaço destinado ao baile. O projeto foi idealizado em 2012 por Marcos Oliveira, diretor da produtora, objetivando ensinar um "funk revolucionário, empoderador e consciente" aos jovens que sonham em seguir carreira dentro do gênero. A participação na Escola depende da comprovação de bom rendimento e frequência escolar.

A educadora Patrícia Beninca, professora da escola - a qual chama de família - responsável pelas aulas de cidadania - conta que são dados temas relevantes para a composição das letras com o intuito de resgatar o fundamento do funk, ou seja, passar uma "ideia consciente". Segundo ela esse seria o verdadeiro sentido do funk (ANEXO, 8). Patrícia conta que faz curso de extensão no 
Instituto de Artes da Universidade Federal do Rio Grande do Sul para educadores de música em comunidades. A educadora ressaltou a existência de menosprezo e fala até mesmo de preconceito dentro da própria comunidade e uma idealização, que não raro por um processo de identificação aos opressores, grupos vulneráveis socialmente reproduzem uma violência simbólica de profundas raízes. Assim, só que "do asfalto pra lá tudo é diferente". (ANEXO, 8).

O Baile Funk da Tuka, como referência nacional, demonstra a complexidade quando lidamos com manifestações culturais marginalizadas, principalmente a partir do potencial em desfazer a necessária vinculação à criminalidade nos bailes - espaço de diversão como outro qualquer que, sob a ótica criminalizante do poder punitivo, recebe os tons sombrios da estigmatização.

Ademais, quando dirigimos nossa escuta na tentativa de estabelecer os contornos mais nítidos das relações entre as forças de repressão e esta manifestação cultural, os resultados são riquíssimos, em especial desde as entrevistas realizadas com os MC's e os policiais militares. Por ali, interpretam-se os enlaces discursivos que traduzem muito bem a cena do Baile Funk da Tuka, muito para além do local, mas como metonímia representativa do fenômeno do funk frente aos aparatos estatais de segurança. As constatações, como em qualquer estudo de observaçãoparticipante, originam-se, neste caso ainda mais, principalmente de conversas informais e da observação direta nos bailes.

Com os "Mestres de Cerimônia", durante o mês de setembro, foram realizadas cinco entrevistas. No decorrer delas, os MCs relataram variadas situações de associação entre preconceito e repressão. Sobre a discriminação naturalizada que o morador da favela recebe, MC Tchesko fala da falta de empatia da "sociedade" com o "favelado":

"Por eu viver na favela, as pessoas imaginam várias coisas, mas não se colocam na pele da pessoa que vive, que sofre um preconceito com discriminação, é com certeza, acho que o ponto máximo nisso é discriminação por morar numa favela, por ser funkeiro, ele não tem aquilo lá agora, ele é favelado, ele não tem, mas depois que ele estoura, ele é bem visto, sabe, porque ele foi um vencedor, mas ele não deixa de um vencedor por morar na favela ou por ainda não alcançar o sucesso, eu acho que falta muito a visão lá na frente das pessoas de dar moral ao ser humano, de não descriminalizar (sic), em vez de pensar pra trás, pensar pra frente. [...]. Eu acredito que seja assim pela criminalidade, racial, como apareceu no samba, acredito muito nisso também." (ANEXO, 1).

MC Tchesko defende que o funk é a voz da favela, é o grito de socorro ao sistema. O artista acredita que as letras expressam um pouco da revolta dos moradores da periferia ante as 
dificuldades que enfrentam, por isso, Tchesko entende que o ritmo como representante cultural desagrada aqueles que não se importam com a vida dentro da favela.

"Tu tá sempre passando por aquilo lá que o funk conta, tu passa por aquilo lá que o rap conta, então isso que não deixa morrer, entendeu? Por isso que o funk é a voz da favela. A voz da favela é o que, é a voz de socorro, ao sistema, sabe? Então os MCs que moram na favela, eles fazem aquilo rindo, por uma repressão policial, ou sei lá, uma repreensão da sociedade que vive longe, por eles serem discriminados por serem tratados diferentes eles sentem na pele, são seres humanos entendeu? E acho que as vezes, um pouco da revolta deles, é passada no funk, as pessoas não gostam de ouvir aquilo lá, mas é o que eles passam. O que eles vão fazer, eles vão falar que tão com dinheiro, vão falar que tão bem de vida? Não, eles vão falar das dificuldades deles do dia a dia, então essa é a voz da favela. " (ANEXO, 1).

MC Sabha, educador no projeto social "Escola de MCs e DJs", narra que já foi vítima de muito preconceito por ser funkeiro. O MC conta que já foi preso durante uma apresentação na região metropolitana de Porto Alegre por não aceitar a investida dos "brigadianos"19 que entraram na casa de shows e exigiram que todos fossem "pra parede" para revista.

"Até então era uma abordagem policial, e eu tava cantando, só que eles ligaram a luz da festa, e tava eu e minha produção toda, e eles tudo "na parede! ", só que como, eu não to fazendo nada de errado, eu tô fazendo o meu show, eu não tô roubando, eu não tô traficando, eu não tô matando ninguém, eu tô fazendo o meu trabalho, eu não tenho que estar em parede nenhuma, entendeu? É um direito que tu tem como pessoa, tu que estuda direito né, obrigação tu receber uma abordagem, mas tu vai querer aceitar, ou não, eu não aceitei essa abordagem [...]" (ANEXO, 3).

Durante a entrevista, Sabha também fala sobre a seletividade das notícias veiculadas pela grande mídia. Afirma que a mídia é responsável por transmitir uma imagem negativa do funk, noticiando apenas os fatos ruins envolvendo o gênero - que repercutem mais - e não dando espaço para projetos como o da Escola de MCs e DJs da Tuca, por exemplo.

"Tu não vai mostrar a escola, que não vai dar mais ibope que mostrar que mataram um guri no baile funk, a morte pode acontecer numa festa sertaneja ou numa rave né? Então o que pra a mídia, a mídia que transforma a cabeça de quem vê né, o que destacaram mais na morte do guri de Charqueadas? Saída de um baile funk. Que marcou? O guri tava num baile funk e morreu. Pra mídia isso daí vai dar notícia, vai dar ibope, então as pessoas que não conhecem funk, não vai deixar o seu filho ir pra baile funk. " (ANEXO, 3).

O discurso de MC Kinho da Tuka não é diferente. Kinho relata que já foi alvo de enorme preconceito por ser funkeiro e que, inclusive no dia da entrevista, foi abordado por policiais militares na comunidade da Tuca. O MC diz que os policiais teriam agido com truculência e se referido de maneira pejorativa ao funk. Afirma:

${ }^{19}$ Como se chamam os policiais da Polícia Militar do Estado do Rio Grande do Sul. 
"Eu sofri bastante vezes já [preconceito], ainda principalmente no começo né, aqui no Rio Grande do Sul até hoje é meio dificultoso de abrir porta pro funk, aqui no Rio Grande do Sul. [...]. Hoje por exemplo, to dentro da comunidade, to correndo as caixas de som pra minha festa e os policial me abordaram né, apontaram o fuzil pra mim e eu levantei as mãos e nada a ver.

(...) bem na rua de cima da minha [na Tuka]:

- [policial] tu não tem passagem;

- [Mc Kinho] não, eu não tenho passagem;

- [policial] o que tu faz da vida?;

- [Mc Kinho] eu canto funk seu, e ele,

- [policial] mas funk não é música, funk é coisa de vocês aí mesmo da comunidade;

- [Mc Kinho] não senhor, mas um show meu da semana paga todo teu salário do mês, eu falei pra ele, daí ele já me rebaixou mais, jogou lá em baixo, falou um monte de coisa do funk, que são tudo maloqueiro, e isso, aquilo... chinelagem" (ANEXO, 4).

Sobre o que expressa o funk, MC Kinho explica que as letras refletem o que acontece dentro da comunidade, da mesma maneira que outros ritmos. Ele afirma que "pra eles" (os indiferentes) ouvir o que a periferia tem a dizer não é interessante.

"[...] mas no funk a gente escreve o que a gente vê, entendeu? Mesma coisa que a Ivete Sangalo, ela escreve o que ela vê, ela escreve o que ela vive na Bahia lá, aqui a gente escreve o que a gente vive dentro da comunidade, é a mesma coisa, não tem diferença. A nossa realidade a gente segue, e pra eles, sei lá, isso não é interessante." (ANEXO, 4).

Na mesma linha, MC Ton aproveitou a oportunidade para ressaltar relação de desrespeito e violência da polícia com o morador da favela:

"Porque tipo, polícia não respeita o morador da favela, polícia entra e não quer saber se favelado trabalha, se favelado tem um emprego, sabe que eles já saem batendo em todo mundo, né." (ANEXO, 5).

A resistência das pessoas em aceitarem o funk como expressão cultural e a constante associação do gênero à criminalidade é explicada de maneira simples e objetiva por MC Ton:

"Creio eu que seja pelo fato de quem faz o funk, senão existisse MC que morra dentro do morro não existiria esse preconceito, essa resistência." (ANEXO, 5).

A declaração de $M C$ Ton sinaliza bem para o âmago da presente pesquisa. O funk como gênero musical não incomoda por si só, mas sim tudo que ele expressa: revolta ante a desigualdade e injustiça social. Na verdade, o que se deseja é silenciar a voz (grito de socorro/denúncia) das populações marginalizadas.

Neste sentido, aos atores policiais envolvidos neste contexto ganham protagonismo de extrema relevância. Entre os dias 16 e 17 de setembro de 2015 foi possível realizar entrevistas com os soldados da 2a Companhia do 19 Batalhão de Polícia Militar (BPM), responsáveis pelo 
policiamento no local onde é realizado o Baile Funk da Tuka. ${ }^{20}$ Durante a aplicação do questionário, pôde-se perceber diretamente como se estabelece a relação entre policiais e funkeiros.

Contudo, cabe frisar que, para além dos dados expostos pelos relatos policiais, importa deparar-se com aquilo que subjaz às declarações acerca das ocorrências registradas no Baile Funk da Tuka.

Preliminarmente, os policiais referiram que nunca houve qualquer pedido de policiamento específico para o Baile Funk da Tuka e, portanto, fazem ronda normal em toda área, independente do acontecimento. Assim, conforme relatos dos policiais, a guarnição só vai até o baile se receber chamado telefônico (190).

Ao serem perguntados sobre a natureza das ocorrências relacionadas ao evento, mencionaram a prática de diversos delitos, principalmente tráfico de drogas, disparo de arma de fogo ("tiroteio") e agressões ("brigas"). Todavia, em relação ao baile supostamente representar risco ou ameaça para a comunidade, emblemática a declaração de um dos policiais militares:

"[Entrevistadora: ]. Acreditas que o baile represente algum risco ou ameaça pra comunidade da Tuka?

[Soldado 01: ] O baile, em si, não, mas, as coisas que provêm do baile funk, atrai (sic) criminosos de outra região, que vem armados, até com o intuito de se proteger de outros inimigos que por ventura venham se encontrar. Dentro do baile funk, na localidade ali, não há grande risco, o problema é a saída, nas ruas próximas, nos ônibus, é onde se registra o maior número de problemas. [...] o baile funk, não o gênero musical, mas da maneira como ele é executado nas periferias hoje, sem sombra de dúvidas, é um fato preocupante. Porque jovens, principalmente adolescentes, se veem bastante frequentemente totalmente embriagados, drogados, sentimento de libertinagem, não respeitam nada e nem ninguém. Esse é um dos grandes problemas assim dessa aglomeração de jovens hoje. Até porque, na maioria das vezes a letra do funk é, ela é uma letra que induz a juventude a cometer criminalidade" (ANEXO 6.1).

A fala dissimula e tenta separar o indissociável: a manifestação cultural do ritmo musical. 0 problema passa a ser o "modo como vem sendo executado" e não "o gênero musical". Portanto, a desqualificação do modo de vida presente ali é exatamente o que expõe a rotulação, e a consequência óbvia disso apenas será dirigida à criminalização de acordo com estes estereótipos

\footnotetext{
${ }^{20}$ No dia 02 de setembro de 2015, no 19 Batalhão de Polícia Militar de Porto Alegre, Rua Coronel Aparício Borges, no 2505, no Bairro Partenon, foi formalizada solicitação do levantamento das ocorrências referentes ao baile e suas proximidades. No dia 09 de setembro, encaminhado por e-mail ao responsável pela 2a Companhia os detalhes sobre o necessário para a realização da pesquisa. Movimento reiterado nos dias 15, 16 e 23 de setembro. Entretanto, infelizmente, não houve qualquer retorno quanto às informações solicitadas acerca da análise da natureza dos delitos, perfil dos envolvidos e a relação dos delitos com o baile. Portanto, maior ainda a importância o estudo sobre os elementos colhidos através da aplicação de questionário (anexo).
} 
(CHAPMAN, 1968). Não será à toa que tal racionalidade concluirá que o universo do funk "induz a criminalidade". Assim, em suma, funciona a seleção criminalizadora policial ou mesmo judicial.

Por outro lado, um dos soldados, em que pese acreditar que o funk não está vinculado a uma determinada classe social, afirma que ele é consumido por comunidades mais pobres e geralmente envolvidas com o tráfico de drogas e que, além disso, por vezes, compõem músicas contra as leis e de afronta à polícia. Aduz, por consequência, que são os próprios funkeiros os responsáveis por sua criminalização. Numa alquimia clássica que está no âmago do discurso do poder punitivo que se acredita neutro e passivo, apenas posto em movimento quando provocado, defende que a polícia não criminaliza o movimento funk, mas sim os próprios funkeiros que se colocariam contra a lei através das letras (ANEXO, 6.2). Ilustrativa por demais a reação do mesmo Soldado quando utilizado na entrevista o termo "órgão repressor" para referir à Polícia Militar. Imediatamente transpareceu seu incômodo e ressaltou a preocupação em não ver a instituição estigmatizada na pesquisa.

Por fim, na oportunidade da entrevista realizada no 19 BPM com o Capitão responsável pela 2a Companhia, no alto de sua posição de suposto "especialista" por "conhecer a zona há mais ou menos 12 anos", notando a evolução da cultura funk local, diz que os bailes eram promovidos apenas visando à bebida e ao tráfico. Defende, não obstante, que não se trata de uma questão cultural, mas sim da lei, sendo "necessário manter a ordem". A introjeção de um conhecimento dado como óbvio é exatamente aquilo com que se alimenta a criminologia midiática (ZAFFARONI, 2013, pp. 193 ss.). E aos atores político-criminais imersos neste caldo de um higienismo social tacanha nada cabe senão depurar os elementos indesejáveis sob o pretexto de manter a ordem. Tudo isto sempre a conduz a respostas urgentes e às falsas soluções repressivas de sempre. A chave desta racionalidade passa precisamente pelo surpreendido aqui nas entrevistas com os agentes de segurança pública: instados a falar do que sabem (organização policial, dificuldades no processo de investigação ou de diagnóstico dos casos que encontram) desembocam a formular respostas que apenas um criminólogo estudioso do tema, se fosse o caso, poderia responder. Em resumo, pretensamente achando que responde a conhecimentos que lhe são comuns e até óbvios adere a uma realidade construída de preconceito dada como certa. Cria-se um pensamento mágico disfarçado de científico pronto a retroalimentar a reprodução dos estigmas. 


\title{
À GUISA DE CONCLUSÃO: MEDO, ESTIGMA E CRIMINALIZAÇÃO - A BATIDA FUNK
}

\author{
Eu já avisei e vou confirmar \\ A voz da favela você tem que respeitar \\ Somos todos iguais mas temos diferenças \\ Vocês lutam pela lei, nós pela sobrevivência \\ (MC TCHESKO, Sobrevivência)
}

Os herdeiros das senzalas deixaram de ser perseguidos por portarem um cavaquinho ou um pandeiro, mas não por se divertirem ao som do "pancadão". Imbricações assim expostas por Nilo Batista:

"As velhas perseguições aos batuques e ao samba encontraram no funk um novo alvo à altura da tradição: também uma arte popular, cultivada pelos estratos sociais mais pobres, irreverente e sensual." (BATISTA, 2013, p. 191).

Associar o funk à criminalidade, à violência e à imoralidade não é mera coincidência, mas sim ampla estratégia nada latente do processo de idiotização da população, no qual a mídia possui grande protagonismo. Fomentar socialmente a ignorância através dos rasteiros discursos do senso comum aliciadores do ódio, através de notícias que teimam em vincular funkeiros ao tráfico de drogas e como supostos agentes da apologia ao crime ou ainda de estímulo à sexualidade precoce, é, além de criar a própria imagem da devassidão e perigo ao "cidadão de bem", manipular o medo, gerir a paranoia social treinando os afetos na direção de um contagioso analfabetismo político.

Segundo Adriana Facina,

"A associação entre artista do funk e "traficantes" como heróis da juventude favelada não é casual. [...] A construção da imagem do traficante como ameaça à sociedade, substituindo outros estereótipos, como o de "comunista", cria um novo inimigo que justifica a continuidade da opressão do povo pobre em novos marcos." (FACINA, 2010).

Em diversos momentos, a imprensa conferiu ao funk um tratamento marginalizante, pressionando o poder público a agir de certa forma quanto ao gênero musical. A cada fato envolvendo o funk, noticiado de forma aterrorizante, as demandas da sociedade para que Estado responda perversa e de maneira repressora ao movimento cresce sem cessar. Assim, o discurso da mídia hegemônica e suas posturas criminalizadoras em relação ao funk se fortalecem, a exemplo da criação de leis limitando a realização de bailes (SANTIAGO, 2013, p. 33).

Sabemos que a linguagem midiática é produtora de afetos. Máquinas que acabam gerando outras máquinas emocionais, quer dizer, subjetividades forjadas e produtoras de determinados sentimentos. Quando operacionalizada sua potência desde uma violência projetiva, como no caso intensificado dos discursos cristalizados de preconceitos, atirados sobre os significantes funk-crimemedo, será o ódio que dominará o campo dos sentidos. Alçado a delírio por engrenagens 
midiaticamente organizadas, este circuito de $\operatorname{afetos}^{21}$ acaba por se fixar como a verdade da experiência social. Neste complexo jogo de forças em que se cruzam dispositivos verticais, como líderes políticos, publicitários, jornalistas etc., associados a esta contagiosa atmosfera de confirmação horizontal de personalidades autoritárias, tais manifestações artísticas acabam por canalizar a paranoia como condição social. Assim, oblitera-se qualquer outro horizonte possível senão aquele sob a égide de um ethos que Márcia Tiburi chamou de "med'ódio": "o modo como se produz o medo relaciona-se diretamente com a produção do ódio. São afetos associados. A sociedade que promove a insegurança - e vende 'segurança' por todos os lados - depende do sucesso do medo. Medo da economia e da política e, em primeira instância, sempre o medo do outro" (TIBURI, 2016, p. 36).

$\mathrm{Na}$ figura do funkeiro, projeta-se o inimigo que, através de uma articulação entre a influência dos meios de comunicação de massa e as atividades dos Poderes Legislativo, Executivo e Judiciário, passa a ser visto como ameaça à moral e aos bons costumes. Portanto, o funkeiro começa a gerar repulsa e, então, torna-se inimigo de toda sociedade. Ao classificar o funkeiro como "inimigo", agente de uma identidade deteriorada desviante (outsider), vemos que tal processo de criminalização trata de uma deliberada filtragem que, além de ser concentrada nos estratos mais pobres da sociedade, é responsável por produzir e construir estereótipos (rótulos) (BECKER, 2008).

Nesse sentido, ao menos desde os estudos criminológicos rotulacionistas (labelling approach), dever-se-ia perceber que a criminalidade é uma realidade socialmente construída e atribuída a determinados indivíduos ou grupos através da ocorrência de processos de criminalização. O paradigma da reação social, como ficou consagrado, foi o radical contraponto à criminologia positivista, e de irretorquível irreversibilidade em suas conquistas críticas (BARATTA, 1999, pp. 112-3). Entre as mais importantes talvez esteja seu recorte preciso de não mais dotar o desviante como simples "objeto de pesquisa" como faziam os positivistas, mas permitir um olhar permeável aos processos sociais de interação simbólica. Não identificar, classificar e controlar o sujeito dito criminoso para extirpá-lo do convívio comum, mas sim estudar os processos de interação (dentre eles as linguagens criminalizantes) sobre os quais eles estão dispostos como "desviantes".

Para Gabriel Anitua, seguindo Frank Tannenbaum, o processo de rotulação se inicia com a atribuição de determinadas características ao sujeito que, devido a elas, será excluído da sociedade

${ }^{21}$ Sobre a importância política de se mergulhar nesta perspectiva, ver SAFATLE, 2015a. 
honrada e então incluído na sociedade delinquencial, já que apenas entre outros delinquentes será capaz de se encaixar. Após, o indivíduo se adequa ao novo ethos de delinquência, o adotando como forma natural de viver. Concomitantemente, gera-se um endurecimento no confronto com as instituições penais, cuja consequência seria a "psicose da guerra" ao delinquente profissional, fomentada pelo medo e pelo anseio de permanecer vivo e livre a qualquer custo (ANITUA, 2008, p. 588).

Sempre presentes deveriam estar as lições da teoria do etiquetamento. Especial trato à clássica obra referida de Howard Becker dedicada ao estudo dos músicos de jazz e dos usuários de maconha. Exame detalhado dos efeitos que a imposição social de um status de desviado desempenha. Segundo Howard Becker, o desvio seria não uma qualidade do ato cometido, tampouco daquele que o comete, mas sim uma consequência da aplicação por outros de regras e sanções a um "infrator". O autor conclui que "desviante é alguém a quem esse rótulo foi aplicado com sucesso; o comportamento desviante é aquele que as pessoas rotulam como tal. " (BECKER, 2008, p. 22). Ou seja, ser desviante é, assim, o resultado de um etiquetamento social e não a consequência de uma conduta praticada.

Por outro lado, na mesma estatura estão os estudos de Erving Goffman, particularmente a obra "Estigma", na qual o colhe especificamente como produto de um tipo especial de relação entre atributos e estereótipo. Portanto, a categorização do "estranho" dá-se por conta de determinados atributos, que o tornam diferente e excluído dos demais. Afirma diretamente que $o$ tratamento despendido a determinados sujeitos é de exclusão e classificação como "indesejáveis, maus, perigosos e fracos. " Assim:

"Deixamos de considerá-lo criatura comum e total, reduzindo-o a uma pessoa estragada e diminuída Tal característica é um estigma, especialmente quando o seu efeito de descrédito é muito grande [...] e constitui uma discrepância específica entre a identidade social virtual e a identidade social real. " (GOFFMAN, 2012, p.12)

O "desviante", reduzido a criminoso pela baixíssima intensidade crítica da linguagem do senso comum, é, portanto, aquele a quem a sociedade atribui tal rótulo em virtude de uma a certa leitura sobre a sua conduta e, sobretudo, devido ao seu índice de marginalização (vulnerabilidade), qual seja: negro, pobre, desempregado, favelado etc. (lembrando a lógica lombrosiana). Ainda que tenha ocorrido uma infração ao Direito Penal, será o comportamento formalmente delituoso somado às posições estigmatizadas que carrega Ihe tornarão realmente dotado deste status perante a sociedade. A marginalização do sujeito corroborada com o mínimo deslize, o transformará em delinquente. 
Refere, Alessandro Baratta que:

"O que é criminalidade se aprende, de fato, pela observação da reação social diante de um comportamento, no contexto da qual um ato é interpretado (de modo valorativo) como criminoso, e o seu autor tratado consequentemente. Partindo de tal observação pode-se facilmente compreender que, para desencadear a reação social, o comportamento deve ser capaz de perturbar a percepção habitual da routine, da 'realidade tomada-por-dada' (taken-for granted reality), ou seja, que suscita, entre as pessoas implicadas, indignação moral, embaraço, irritação, sentimento de culpa e outros sentimentos análogos." (BARATTA, 1999, p. 95).

Frise-se que, para a construção do rótulo "criminoso", não é suficiente a mera prática de ato tipificado como ilícito penal, senão é necessária a reação social, isto é, que o agente desviante seja alvo da atuação das instâncias oficiais (e não oficiais) de controle social e que seja selecionado a integrar o grupo dos indivíduos vistos como tal.

Tendo por adquirido tudo aquilo que rapidamente fora apontado, pode-se também entender a criminalização do funk como consequência da reação social que este provoca na sociedade. Melhor dizendo, músicas que trazem à tona problemas sociais como desigualdade, violência, consumo de drogas etc., ou seja, ecoam uma realidade vivida nos morros e comunidades do Brasil, geram, além da repulsa "natural" por serem provenientes de estratos mais carentes da sociedade (preconceito nato), irritação e perturbação da percepção habitual da rotina. A indiferença completa à vida nas periferias brasileira é o obsceno da exceção ardilosamente naturalizada. Nada muda manifestação cultural sobre a qual é preferível se adotar permanentes mecanismos de silenciamento. Nada há ali para se dizer, portanto, nada por se escutar.

Não desprezemos, por outro lado, o mal-estar que este estado de coisas, audível nestes discursos, pode desencadear. Qualquer cidadão minimamente compassivo deve (ria) se incomodar ao ouvir o que relatam algumas destas letras de funk: crianças recrutadas pelo tráfico de drogas, o sangue escorrendo pelas escadarias e barracos do morro, jovens nulificados de um futuro senão pela visibilidade criminal etc. Testemunhos que nos atiram claramente diante da responsabilidade sobre as opções políticas e criminais de um estado que marginaliza, aprisiona e mata em defesa do capital. Quando se aprende que a criminalidade é uma definição e não uma realidade objetiva, somos tomados pela capacidade imperativa de interrogar imediatamente quem tem o poder de definir e quem sofre a definição. A partir disso, responder a que $(\mathrm{m})$ interessa criar uma imagem de desordem, terror e instabilidade relacionada à periferia.

Sobre a verdadeira faceta da criminalização do funk, Adriana Facina elucida:

"Criminalizar a cultura funk, incluindo-se aí o proibidão, é criminalizar os pobres. [...]. Portanto, fica claro que o problema não é tanto o funk (que, 
aliás, continua a ser tocado em boates da Zona Sul, festa em condomínios de classe média, clubes fechados, etc.), mas sim quem produz e se diverte com ele." (FACINA, 2010, p. 59)

Ao contrário do rótulo preconceituoso e discriminatório imposto aos bailes funk, percebese que estes, assim como qualquer outra festa, são espaço cultural de lazer e diversão. Canalha é a associação banal dos bailes à criminalidade e à "selvageria".

"Um dos grandes mitos, sustentado pelas forças policiais e pela imprensa, é a de que bailes funk provocam violência e o aumento de ocorrências que ameaçam a ordem urbana. No entanto, sabemos que tais fatos não são exclusivos de bailes funk e sim comuns a qualquer tipo de aglomeração, sobretudo as que envolvem a juventude [...]. Do mesmo modo, micaretas, o réveillon de Copacabana, festas em boates, chopadas e por aí vai. " (FACINA, 2010, pp. 59-60).

Os bailes funk são proibidos sob o pretexto de serem o "antro da criminalidade". Entretanto, singelo entender que o cometimento de crimes em festas não é exclusividade de bailes funk. Nem precisaríamos aludir quaisquer festas em algum condomínio fechado por alguma zona nobre de alguma cidade do Brasil. Mais palatável insistir em ver o perigo apenas no que vem do estrato mais vulnerável da sociedade, o que denota além da lógica do recorte de classe e de raça, a evidente tentativa de extermínio do "indesejável" (BAUMANN, 1998, p. 13-120).

A importância de análise deste estilo musical está naturalmente por ser, repita-se, um modo de vida, na medida em que a musicalidade jamais deixará de ser expressão da linguagem e, por seus vínculos, uma maneira de construir o espaço social. O funk, portanto, como expressão cultural, veicula afetos que singularizam as comunidades que o vive. Atentos estamos ao alerta de Safatle (2015b; 2015c), e não estamos nos acovardando sobre qualquer inteligência crítica a qual veria o funk como ideia da equivocada existência de uma "cultura proletária". Muito menos o enxergaríamos de maneira unívoca, procedendo a uma indiferenciação daquilo que também ali pode estar presente, como a "simplicidade formal", a "estereotipia dos afetos", a "fácil cognição" e uma mera ostentação de uma "inserção social conformista" - formas que expõem a farsa de um "popular" que nem de perto "abala os alicerces" da classe dominante. Nossa preocupação coaduna-se com isso, e aponta exatamente que, para além da qualidade discutível do que se produz, há a planificação destas complexidades exatamente pelo poder punitivo. Independente dos modos que o funk se põe e do juízo estético possível (e extremamente necessário de ser feito) diante disso, este mundo é integrado absolutamente como alvo da repressão penal.

Na realidade, muito para além de silenciar um ritmo musical, neste caso o funk, busca- se, via criminalização, o extermínio legitimado da pobreza. Administrar a miséria por intermédio da 
repressão penal ${ }^{22}$ de suas tradições, valores, culturas e lazer. Diga-se, por fim, à exaustão: por detrás do processo (sempre seletivo) de criminalização das manifestações culturais concentradas nos estratos mais pobres da sociedade está o desejo de criminalizar e eliminar o público que se identifica com estas expressões: o jovem negro, pobre e favelado.

\section{REFERÊNCIAS}

ALVES FILHO, Bernardo. A Pré-história do Samba. Petrolina: edição do autor, 2002.

ANITUA, Gabriel Ignácio. Histórias dos Pensamentos Criminológicos. Rio de Janeiro: Revan, 2008.

BARATTA, Alessandro. Criminologia Crítica e Crítica do Direito Penal: introdução à sociologia do direito penal. Tradução de Juarez Cirino dos Santos. 2a Ed.. Rio de Janeiro: Freitas Bastos, Instituto Carioca de Criminologia, 1999.

BATISTA, Nilo. "Sobre a criminalização do funk carioca". In: Tamborzão: olhares sobre a criminalização do funk. Criminologia de Cordel 2. BATISTA, Nilo et al. Rio de Janeiro: Revan, 2013.

BATISTA, Vera Malaguti. Introdução Crítica à Criminologia Brasileira. Rio de Janeiro: Revan, 2011.

BAUMANN, Zigmunt. Mal-Estar da Pós-modernidade. Rio de Janeiro: Jorge Zahar, 1998.

BECKER, Howard Saul. Outsiders: estudo de sociologia do desvio. Rio de Janeiro: Zahar, 2008.

CARVALHO, Salo de. "Criminologia Cultural, complexidade e as fronteiras de pesquisa nas ciências criminais". In: Revista Brasileira de Ciências Criminais, ano 17, n. 81, nov. - dez. /2009, pp. 294-338.

CHAPMAN, Denis. Sociology and the Stereotype of the Criminal. London: Tavistock, 1968.

COHEN, Albert K. Delinquent Boys: The Culture of the Gang. New York: Free Press/Macmillan Publishing, 1955.

CYMROT, Daniel. "Criminalização do Funk e Extermínio de MCs". In: Folha de São Paulo, São Paulo, no 13 (jun. 2012).

"'Proibidão' de colarinho-branco". In: Tamborzão: olhares sobre a criminalização do funk. Criminologia de Cordel 2. BATISTA, Nilo et al. Rio de Janeiro: Revan, 2013, pp. 73-104.

DOPA - Diário Oficial de Porto Alegre. Câmara Municipal. Lei no 10.987, de 6 de dezembro de 2010. Câmara Municipal. Lei no 11.682, de 25 de setembro de 2014.

ESSINGER, Silvio. Batidão: uma história do funk. Rio de Janeiro: Record, 2005.

FACINA, Adriana. "A "eu só quero é ser feliz": quem é a juventude funkeira no Rio de Janeiro? " In: Revista EPOS, Rio de Janeiro, v.1, n. 02, out. 2010.

22 WACQUANT, Loïc. Punir os Pobres: A nova gestão da miséria nos Estados Unidos [A Onda Punitiva]. Tradução de Sérgio Lamarão. 3a Ed. Revista e ampliada. Rio de Janeiro: Revan, 2007, pp. 85 ss. 
"Quem tem medo do 'proibidão'". In: Tamborzão: olhares sobre a criminalização do funk. Criminologia de Cordel 2. BATISTA, Nilo et al. Rio de Janeiro: Revan, 2013, pp. 51-72.

FERRELL, Jeff; SANDERS, Clinton R. Cultural Criminology. Boston: Northeastern University Press, 1995.

FERRELL, Jeff; HAYWARD, Keith; MORRISON, Wayne; PRESDEE, Mike (eds.). Cultural Criminology Unleashed. London: Glasshouse Press, 2004.

FRAGA, Vitor. "Projeto relaciona Direito Penal e criminalização do samba". OAB/RJDigital, Rio de Janeiro, mai. 2013.

FRANCISCO, Dalmir. "Arrastão Mediático e Racismo". In: DCS/FAFICH/UFMG. GABEIRA, Fernando. A Maconha. São Paulo: PubliFolha, 2000.

GOFFMAN, Erving. Estigma: notas sobre a manipulação da identidade deteriorada. 4. ed. Rio de Janeiro: LTC, 2012.

HERSCHMANN, Micael. O funk e o hip-hop invadem a cena. Rio de Janeiro: UFRJ, 2000. HOBSBAWM, Eric. Bandidos. Rio de Janeiro: Forense Universitária, 1976.

HIRATA, Daniel Veloso. Sobreviver na Diversidade: entre o mercado e a vida. Tese apresentada ao Programa de Pós-Graduação em Sociologia da Faculdade de Filosofia, Letras e Ciências Humanas. Universidade de São Paulo, 2010.

MARTINS, Denis Moreira Monassa. Direito e Cultura Popular: o batidão do funk carioca no ordenamento jurídico. Rio de Janeiro: UERJ, 2006 (monografia de graduação em Direito).

MEDEIROS, Janaína. Funk Carioca: crime ou cultura? O som dá medo. E prazer. São Paulo: Terceiro Nome, 2006.

MOURA, Roberto. Tia Ciata e a pequena África no Rio de Janeiro. 2a Ed. Rio de Janeiro: FUNARTE, 1995.

PALOMBINI, Carlos. "Musicologia e Direito na Faixa de Gaza". In: Tamborzão: olhares sobre a criminalização do funk. Criminologia de Cordel 2. BATISTA, Nilo et al. Rio de Janeiro: Revan, 2013, pp. 133-172.

PEREIRA, Camila Stella Toledo. Cultura ou polícia? A cobertura jornalística do funk carioca em Porto Alegre. (Monografia de Conclusão do Curso de Comunicação Social). Universidade Federal do Rio Grande do Sul, 2010.

PIERANGell. José Henrique. Códigos Penais no Brasil: Evolução Histórica. 2a Ed. São Paulo: RT, 2001.

PINTO, Charles di; BORBA, Gustavo. Fragmentos de Memória do Rock Gaúcho. São Leopoldo: Editora Unisinos, 2014. 
PRESDEE, Mike. Cutural Criminology and the Carnival of Crime. London/New York: Routledge, 2000.

RIBEIRO, Darcy. O Povo Brasileiro: a formação e o sentido do Brasil. 2a Ed. São Paulo: Companhia das Letras, 1995.

SAFATLE, Vladimir. O Circuito dos Afetos: Corpos políticos, desamparo e o fim do indivíduo. São Paulo: Cosac Naify, 2015a.

"O fim da música". In: Folha de S. Paulo, 09/10/2015b.

"Os alicerces da cidade". In: Folha de S. Paulo, 16/10/2015c.

SALLES, Écio. "Funk, samba e a produção do comum: diálogos, sons, interações". In: Revista da Associação Nacional dos Programas de Pós-Graduação em Comunicação, Rio de Janeiro, abr. 2007.

SANTIAGO, Tainá Barbosa. É som de preto, de favelado e caso de polícia: a criminalização do funk e sua correlação com o poder público e a mídia. Niterói: UFF, 2013.

TIBURI, Márcia. Como conversar com um Fascista: reflexões sobre o cotidiano autoritário brasileiro. São Paulo: Record, 2016.

VELLOSO, Mônica Pimenta. As Tias Baianas Tomam Conta do Pedaço: Espaço e Identidade Cultural no Rio de Janeiro. Revista Estudos Históricos, Rio de Janeiro, v. 3, n. 6, pp. 207- 243.

VIANNA, Hermano. O Baile Funk Carioca: Festas e Estilos de Vida Metropolitanos. Rio de Janeiro: UFRJ, 1987.

VIANNA, Hermano (Org.). Galeras cariocas: territórios de conflitos e encontros culturais. Rio de Janeiro: UFRJ, 1997.

WACQUANT, Loïc. Punir os Pobres: A nova gestão da miséria nos Estados Unidos [A Onda Punitiva]. Tradução de Sérgio Lamarão. 3a Ed. Revista e ampliada. Rio de Janeiro: Revan, 2007.

ZAFFARONI, Eugenio Raúl. A Questão Criminal. Tradução Sérgio Lamarão. Rio de Janeiro: Revan, 2013.

Trabalho enviado em 14 de setembro de 2016.

Aceito em 14 de dezembro de 2016. 